\title{
Epistemological Responsibility and A Candle in the Darkness: A Review of Robert D. Stolorow's Trauma and Human Existence
}

\author{
Tor-Johan Ekeland, Volda University College, Norway \\ Email: tie@hivolda.no
}

In his preface to Trauma and Human Existence: Autobiographical, Psychoanalytic, and Philosophical Reflections, Robert D. Stolorow presents his work as an inquiry that interweaves "the conceptuality of emotional life in general and emotional trauma in particular," focusing particularly on "the possibility that emotional trauma is built into the constitution of human existence” (p.xi). Stolorow's inquiry is relevant not only to emotional trauma, but also advances our understanding of mental suffering and illnesses. Metatheoretical perspectives do not necessarily offer profound questions; they instead go straight to the heart of what may be called the "epistemological torment" in Western psychiatry. Initially, however, as I reflected on this book and on these questions, and the deep thinking they imply, my skepticism grew, since they were all to be handled in a very slim volume of a meager 62 pages. Further compounding my initial impression that this book did not delve into its subject matter in a sufficiently in-depth manner was the fact that Stolorow interweaves unwieldy theoretical considerations together with a deeply personal narrative. How can the personal become epistemologically relevant? My initial hunch, while dipping into the book, was that great questions usually accompany great ambitions, but on a first reading one could claim this book seemed to be all out of proportion. However, the author has carefully integrated theoretical and philosophical concerns, and his own experiences of traumatic loss demonstrating the point from Husserl -beyond subjectivity we can reach something common to all humankind.

Stolorow is a psychoanalyst and clinical professor of psychiatry at the UCLA School of Medicine, and has published extensively on the relationship between psychoanalytic theory and practice on the one hand, and philosophical questions on the other. He is well known for his works on the theoretical reformulation of orthodox psychoanalysis in books like Faces in a Cloud (1979), Structures of Subjectivity (1984), Psychoanalytic Treatment: An Intersubjective Approach (1987, with Brandchaft), and Context of Being (1992, with Atwood). Noting Stolorow's track record, and being aware of his credentials in philosophy, including clinical psychology and in psychoanalysis, I suppressed my initial scepticism. I decided to give Stolorow's work a chance.

Trauma and Human Existence is Volume 23 in the "Psychoanalytic Inquiry Book Series," and consists of seven fairly easy to read chapters. Each chapter, moreover, can function as a separate essay independent of its place in the book. The accessibility of the author's writing is supported by his easy alternation between clinical and autobiographical vignettes, consistently guided as it is by theoretical and philosophical questions. However, this initial sense of readability is rather deceptive, because easy to read does not always mean easy to understand in-depth. I discovered that the intellectual challenge increases in Chapter

5, entitled Trauma and the "Ontological Unconscious," where Stolorow opens with no less than five quotations from the philosophers Hans-Georg Gadamer, Ludwig Wittgenstein, 
Jacques Lacan, and Martin Heidegger. Readers unfamiliar with Heidegger's thinking may have some problems in understanding the depth of this book, because Heidegger's presence here is, so to speak, a kind of "being-in-the-text." However, the book may inspire further studies of this important philosopher with his stubborn "jargon," as Theodore Adorno (2003, p. 3) once put it. Without being a Heideggerian myself, I acknowledge his philosophy to be an important turning point, not only for (post-)Cartesian thinking, but in the Western tradition of philosophy in general.

In this review-essay, I start with a short summative and descriptive overview, chapter by chapter, which focuses on the author's ideas and message. I then discuss some of the thoughts I had while reading -reflections that concern important epistemological questions that go far beyond the scope of the text itself. A text's ability to create reflective association is usually indicative of its importance, and this text is no exception.

In Chapter 1, “The Contextuality of Emotional Life," Stolorow presents his epistemological point of departure and argues for what he holds to be a central tenet in "intersubjective-system theory" -that a shift in psychoanalytic thinking from the primacy of drives to affectivity will help move psychoanalysis toward a more phenomenological contextualism. In general, this assertion is not in line with Cartesian thinking and the psychoanalytic version of it. As Stolorow states, the mind cannot be conceptualized as an isolated objective entity.

Heidegger's concept of Befindlichkeit is introduced as a way of repairing the Cartesian subject-object split and contextualizing the human mind and body as embedded and engaged in the world-in other words, as being inseparable. This concept is related to the following familiar question, "how are you doing?" rendered in German as "Wie befinden Sie sich?" The question literally asks how one "finds" oneself, requiring the person to find how he is; and when he does, he must find himself amidst his or her life circumstances. The term, in other words, denotes how we sense ourselves in situations, and highlights that we are always situated in a context, in the world, living in a certain way with others, trying to achieve, and in some instances, to avoid, some situations. Affectivity and emotional experience are similarly situated, and Storolow characterizes them as relational, as being inseparable from intersubjectivity. When a child's affective states cannot be integrated because they evoke massive or consistent mal-attunement from caregivers, psychological conflicts may develop. Epistemologically, developmental trauma is placed within an emergent intersubjective context, and not as coming from an "instinctual flooding of an ill-equipped Cartesian container” (p. 3).

This perspective is deepened by the discussion in Chapter 2, "The Contextuality of Emotional Trauma." Stolorow presents a therapeutic case in which a young woman displays the bodily symptoms of shaking and flushing, which can be indicative of an experience of sexual abuse. During therapy, the woman's traumatized state underwent a transformation -instead of only shaking she started to use words and to speak of her terrifying experience. Only once before had she tried to speak about this, to her mother, resulting in her mother shaming her and accusing her of being wicked for making up such lies about her father. Stolorow asks provocatively: does the Freudian theory of trauma help us to understand such cases? His conclusion is negative. Stolorow sees trauma, in essence, as an experience of unbearable affect. However, it is not painful feelings in themselves, or their intensity which cause trauma. "Pain is not pathology" (p. 10), as Storolow says. When severe emotional pain "cannot find a relational home in which it can be held" he says, it can become unendurable and traumatic (p. 10). One implication for therapy, from Stolorow's perspective, is that when emotional intensity is situated in an analytical relationship, a fear or anticipation of retraumatisation can be elicited; and this can be part of patient resistance to psychoanalysis or similar therapies. 
I have come to understand that Stolorow endorses the epistemological position that it is not the world in itself, but experiential and subjective meanings which are the realm of psychology. His challenging of Freud might just as well be a challenge, for example, to mainstream posttraumatic stress disorder (PTSD) research today, which tries to develop and globalize standards based on exposure to traumatic stimuli per se. A general epistemological alternative, as I see it, is this: mental illness (whatever the reasons) is a kind of breakdown in the sustainable meaning-systems that make it possible to act and be a subject in the world. The implication is that therapy (whatever form it takes) is a kind of relational meaningmaking and meaning-restoration (Ekeland, 1997).

Chapter 3 in Storolow's book, "The Phenomenology of Trauma and the Absolutism of Everyday Life," starts with an autobiographical account of a traumatic event. It begins with Storolow attending a professional conference some 18 months after the death of his beloved wife. He describes himself proudly picking up a copy of his newly-published book from a display table, and looking "around excitedly for my late wife, Daphne... who would be so pleased and happy to see it” (p. 13). The profound experience of her irretrievable absence at that moment left the author spending "the remainder of that conference...consumed with feelings of horror and sorrow over what happened" to his wife and to himself (p. 14). A phenomenology description of this kind shows trauma to be a kind of estrangement and breakdown of the stability, security, and predictability of the experienced world in general. The beliefs that allow us to function in the world, and to experience it as stable and predictable, are what Stolorow calls the "absolutisms of everyday life.” It is the disintegration of these absolutes that represents a massive loss of innocence, and that exposes the inescapable contingency of our lives in a universe that is random and unpredictable and in which no safety or continuity of being can be fully assured.

Chapter 4, "Trauma and Temporality," consists of five vignettes -one even featuring Harry Potter as a severely traumatized boy. The vignettes form a bridge to a phenomenological discussion of temporality as an important aspect in trauma. Stolorow draws on a key concept of Heidegger, ecstases, which gives to every experience three temporal dimensions or aspects: past, present and future. Each points to the other, unifying the meaning of our existence in terms that are fundamentally historical. Trauma disturbs this unity that makes the coherent and meaningful experience of the world possible. Stolorow's suggestion is that clinical features typically explained as dissociation and multiplicity can be comprehended from this perspective.

In Chapter 5, "Trauma and the 'Ontological Unconscious,"” Stolorow again starts with a personal account as a springboard into a theoretical discussion of "the contextuality of the several varieties of unconsciousness" (p. 24), and an introduction to one type of unconsciousenss in particular labeled by Storolow "the ontological unconscious" (p. 24). Like the story presented in chapter three, this personal anecdote is a moving one, in contrast to the more lexical presentations of different forms of the unconscious. In my mind, Stolorow's reasoning at this point verges on a regression to Cartesian thinking, even if Heidegger's concept of authenticity is the basis for his analysis. To simplify what I see as the main idea, the line of demarcation between the unconscious and consciousness, he argues, cannot be seen as fixed. Rather, this demarcation is related to language and symbolization and to "emergent properties of ongoing, dynamic, intersubjective systems" (p. 28) -in other words, it is contextually embedded. Stolorow's use of the phrase "ontological unconsciousness" to denote a loss of a sense of one's being has to be understood in this contextual perspective.

Chapter 5 closes with a short but interesting Heideggerian reflection on how a loss of a sense of being is, in fact, a loss of being itself, and how this can be seen in terms of a phenomenology of psychotic states and the experience of personal annihilation. This perspective and way of thinking have, in my opinion, important implications for treatment and 
how we organize the mental health field. I believe that Stolorow's discussion would benefit greatly from an examination of these implications.

The current focus on what works and on evidence-based research and practice has the effect of oversimplifying understandings and treatments of anxiety, reducing these to a question of cognitive failure, to be "quick-fixed" by a dose of Cognitive Behavior Therapy. In contrast to this superficial view, Storolow's consideration of "Anxiety, Authenticity, and Trauma” in Chapter 6 is steeped in the tradition of ontological reflection. Stolorow initiates the discussion with the traditional Freudian distinction between fear and anxiety -traumatic and signal anxiety- but only as a starting point. Using Heidegger's conceptualization of anxiety, Storolow articulates an extraordinarily rich understanding of different states of anxiety, including its extreme and traumatic forms. For Heidegger, perhaps inspired by Kierkegaard, anxiety is the key to the person. What is special about anxiety is that through it, Dasein can lose its world. It can lead to an experience of the world as unheimlich (without home), which in direct translation also means frightful. In anxiety, Dasein is pulled out of its embedded familiarity in the world; the "enactment" is broken, to allude to Weber. Stolorow's thesis is that emotional trauma produces an affective state whose features bear a close resemblance to central elements in Heidegger. Referencing his experience of trauma 18 months after the loss of his wife, Storolow remarks on "how closely" his own "description of [his] traumatized state resembles Heidegger's depiction of anxiety" (p. 40). However, Storolow's use of Heidegger to validate his own theory can be criticized as tautological, given Heidegger's ontology serves as the starting point for Stolorow's theorizing in general.

Chapter 7, "Conclusion: Sibling in the Same Darkness," considers the interconnection of the book's the two central themes: 1) the contextual, embedded nature of emotional life and trauma, and 2) the recognition that emotional trauma is constitutive of human existence. Stolorow interrogates their relationship by asking: "How can it be that emotional trauma is so profoundly context dependent and, at the same time, that the possibility of emotional trauma is a fundamental constituent of our existential constitution?" (p. 47) "How can something at the same time be both exquisitely context sensitive and contingent, and at the same time given a priori?” (p. 48). In attempting to reconcile these two seemingly incompatible ideas, Stolorow's starting point is a critique of Heidegger's concept of authentic selfhood and the non-relationality of finitude. Following other critics of Heidegger, Storolow notes the impoverished nature of Heidegger's articulation of "being-with.” There is nothing about love in Being and Time, as he says. Stolorow's view on death is deeply relational and he concludes that our pre-given longing for twinship or emotional kinship is essentially the baseline which makes us reactive to emotional trauma. Stolorow's slim volume produced many insights and connections for me as I read it. The rest of this review expands on the reflections I had while reading the book -reflections, even if they go beyond the text, shows its relevance to an epistemological debate in the mental health field.

Stolorow is well known within the psychoanalytic community as a Freudian revisionist who has, within the alternative approach called "intersubjective psychoanalysis," critiqued traditional psychoanalysis for fabricating "the myth of the isolated mind" (Stolorow \& Atwood, 1992, p. 7). In my opinion, this is not only relevant for psychoanalysis, but is in fact an epistemological prejudice in mainstream Western psychology in general (Ekeland, 2007). I assume that there is a great deal of opposition to a position like Stolorow's within the more orthodox and naturalistic parts of the psychoanalytic community. But I also wonder how much of Freud's original psychoanalysis remains in Stolorow's version. This is tangential here, but when scholars start dissociating themselves from Cartesian dualism, I always become concerned, because this distantiation is very difficult. The manner in which we distance ourselves from the mind-body divide often simply shows how trapped we are in our own dualistic heritage. Gregory Bateson once said that we are balancing on a knife-edge, and 
that we must take pains to avoid falling into the materialistic or mentalistic abysses that lie on either side. According to Bateson, mind is a function of all life, but mind in itself "is nothing" -in the sense of not being a "thing." The mental deals with the world of substance, but is not in itself a substance. It is about relations between substances, and relations are in-between. Bateson borrows the terms pleroma and creatura from Jung to explain further. Pleroma refers to outstretched matter, the physical universe in which particles and energy are the basic elements. Creatura refers to the mental, the meaning system created by human beings in which information is the "fundamental particle." These are not two separate worlds, but necessarily related to each other: "Apart from creatura, nothing can be known, apart from pleroma, there is nothing there to be known” (Bateson, 1987, p. 200).

All biological life can be informed by its surroundings and therefore can be said to have mentality, but of course always a mentality that is in accordance with the biological organization. The level of mentality that the human organism can exhibit is a way in which our biology expresses its adaptive capacity. As symbolic animals we are not locked up in the world; the capacity to symbolize (digitalize) is a semiotic freedom to stand vis-à-vis the world and make multi versions of it. This capacity to organize and create systems of information is what we experience as meaning. To have meaning is to create relationships, to generate the pattern of relationships that binds our world together. The meaning of meaning is adaptation, on the personal as well as on the cultural level.

Freud's theory of drives has been sharply criticized both from inside and outside psychoanalysis, and I agree with most of the criticism. But even if, as Stolorow claims, both the self and psychopathology develop in social systems, we still have biological bodies. I do not understand why modern psychoanalysts turn their backs on the Freudian theory of drives when emotions and relations are their theoretical focus. To be epistemologically responsible it is necessary to argue that there are forces in human life which humans cannot control. Why is it not possible to mount a phenomenological defense of a theory of drives? The question is still how drives operate or make us driven, and the answer that it is either Freud's theory or no theory at all is insufficient. This point is not developed with sufficient clarity in Stolorow's phenomenological psychoanalysis; and perhaps it is the case that his argument with Cartesian dualism ultimately has him falling from Bateson's knife-edge, into the endless depths of mentalism.

I would guess that there are some Heideggerians who have their reservations about Stolorow's use of Heidegger, or the possibility of Heidegger becoming a psychoanalyst. That aside, what I also wonder about is why efforts to give psychoanalysis a phenomenological footing have not succeeded before. Storolow's is not the first attempt. Swiss psychiatrist Ludwig Binswanger (1881-1966) pioneered such an attempt his 1943 book Grundformen und Erkenntnis menschlichen Daseins. This work used Heidegger's concepts as analytical and therapeutic tools, helping the client to see and to understand his or her way of being-in-the world, and to resume and restore the responsibility which existence presupposes. Another Swiss psychoanalyst, Medard Boss (1903-1990), once in analysis on the couch of Freud himself, became skeptical of the naturalist impulse in psychoanalysis. Again, based largely on the philosophy of his friend and mentor, Martin Heidegger, Boss named his method of psychotherapy "Daseinsanalysis." A more contemporary contribution in this connection is the theoretical and philosophical work of the French philosopher Paul Ricoeur (1913-2005). His reading of Freud, and his interpretation of psychoanalysis, as in A Modern Dialogue with Freud: Freud and Philosophy (1970), is a very valuable contribution. Why have these different efforts remained on the margins of psychiatry and clinical psychology, having little influence on the mainstream?

I have no readymade answer. But it is claimed that when René Descartes divided the world as he did, it was not only an epistemological act, it was first and foremost a political act 
(Bernal, 1978). Well informed as he was about the risk of becoming a heretic, he opened up room for the new natural sciences by giving them res extensa, without interfering with res cogitans and the hegemony of the church. The division served an ideological function. Freud was one of the first to challenge the domain called res cogitans, reducing the soul to a secular psyche. In so doing, I see him as a crypto-phenomenologist, confined by his time to scientific, positivistic ambitions. Freud wanted, and wanted very much, to develop a science of the mind, a physic of the soul. In this sense, he was a positivist and modernist of his time. What he achieved, however, was to mark a hermeneutical turning point. The climax of the period of enlightenment and science, is also the context in which psychiatry as well as modern medicine emerged and developed. In principle, everything was accessible to objective research; everything could in theory be understood. As with plants and animals, one believed that the humans' exact place in nature could be determined by means of a combination of observation, measurement and comparison between groups. Psychiatry presented itself within this context as an order which promised to put things in their proper places, and take control of madness in the same way as science gained control in other domains. Freud was a part of this Zeitgeist. When he entered the scene, the observing clinical gaze dominated mainstream psychiatry. Madness was an object to be scrutinized by the penetrating of science. Psychiatry was practiced without a subject. The focus was on madness itself, not on the person who was afflicted. The affected person was both without speech and language until Sigmund Freud started using his ears and replaced the gaze with listening, i.e. listening to the person as a subject. Freud's attempt to understand madness as seen in the light of the affected person's life, his biography and psychology, was in fact a revolution. In my opinion, his thinking and clinical practice was hermeneutic, but his presentation and conceptualization were scientific: Freud analyzed intentionality from the perspective of causality, so to speak. My point is this: If Freud had been a phenomenologist in the open, would psychoanalysis have become established in western society as it did? I think not. Mainstream psychoanalysis fit well into a scientifically-oriented society by giving hope to the technological ambition to master not only nature, but the human soul as well. That is ideology.

Not being a part of the epistemological communities of psychoanalysis or phenomenology, I like revisionists like Stolorow, especially when the alternative is dogmatism. Being a social psychologist and epistemologist interested in the field of mental health (and especially in forms of treatment in the history of psychiatry), I claim there is too little theoretical revisionism in this field today. The historical wrongdoings in psychiatry cannot be explained away in terms of specific moral or intellectual failings of a given time. They are deeply anchored in the epistemological error and Western hubris that assumes that the world can be mastered and controlled. Epistemological error, a concept I borrow from Bateson (1987) is particularly tricky because errors of these kinds actually govern experience, rather than being directly contradicted by it. They cannot be easily submitted to an empirical test. In the long run, however, epistemological errors reveal themselves in practice through their systemic and ecological consequences.

Historically, mainstream psychiatry has been founded in an object-ontology. I hold this to be an epistemological error, which generates insensitivity to agency and subjectivity, to contextual relations and to psychiatry's own moral and ideological functions. In a clinical context, it has the effect of integrating the "other" into a causally deterministic scheme, or into a "natural" context bounded by a biological horizon. Phenomena become automatic reactions, technical errors, or delusions that, whether biological or cognitive, refer neither to reality nor to the "self." In other words, mental suffering has no intentionality; it is in principle without meaning. To reduce what is subjective to something entirely objective is to render the subject mute, to deny him a position as a speaking "I." This makes the relation between practitioner and client subject to manipulation, control, human engineering and a range of other 
possibilities for the abuse of power. It is only by maintaining the other in the position of subject that he or she becomes a fellow human being. History shows that we need this protection to guard ourselves against our own capacity for inhumanity.

In the present day, when Freud and psychoanalysis are widely rejected, and scholars like Stolorow are confined to narrowing intellectual enclaves, it is the epistemology of a contemporary of Freud, Emil Kraepelin (1856-1926), that has been rehabilitated and modernized as hegemonic, in the form of the latest versions of DSM -the American Psychiatric Association's "Diagnostic and Statistical Manual of Mental Disorders." Kraepelin's epistemology is one that fits well with the new neurobiology and the causal schemes associated with imbalances in chemical substances in the brain. This is a new kind of alienation that confuses brain and mind, etiology and correlation. It stems from a confusion of subject-ontology with object-ontology. The person as agent, acting within a world, a moral ecology and a cultural web of meaning, is again seen as a surface appearance. What really matters is the machinery and mechanism underneath, operating in the realm of causality which makes him tick. This is psychiatry without a subject. So here we are again: We may have new knowledge, but we are still trapped by an old epistemological problem.

In Vienna in May of 1935, Edmund Husserl delivered a lecture on the topic of "Philosophy in the Crisis of European Mankind" and a series of lectures on "The Crisis of European Sciences and Psychology" later the same year in Prague. The crisis was the fateful separation of the predictive natural sciences from the realm of human experience and the life of human subjectivity. This separation made values disappear, leaving behind only naked facts. Phenomenology in this sense can be seen as Husserl's crisis therapy (Elveton, 2007). The crisis continues unabated to this day, and phenomenological and epistemological therapies are still needed. Robert Stolorow's Trauma and Human Existence is in this sense a good dose of medicine. At the factual level it is about personal and individual trauma, and as such, is moving and thoughtful. At the epistemological level it is concerned with erroneous conceptions, with an ecological ignorance that neglects the deep embeddedness of humans in systemic relations with others' experience and the surroundings. We are, despite this neglect, "siblings in the same darkness," as Stolorow says (p. 47). If we wish to take up our epistemological responsibility, this tiny book is a candle in the darkness.

\section{References}

Adorno, T. (2003). The Jargon of Authenticity. London: Routledge.

Bateson, G. \& Bateson, M.C. (1987). Angels fear: Towards an epistemology of the sacred. New York: Macmillan.

Bernal, J. D. (1978). Vitenskapens historie (Science in History). Oslo: Pax forlag.

Elveton, Roy. (September 2003). Edmund Husserl. The Literary Encyclopedia, 26. Retrieved July 6, 2009, from http://www.litencyc.com/php/speople.php?rec=true $\& U I D=2274$.

Ekeland, T-J. (1997). The healing context and efficacy in psychotherapy: Psychotherapy and the placebo phenomenon. International Journal of Psychotherapy, 2, 77-87.

Ekeland, T-J. (2007). Epistemological errors and return of the Jedi. Impuls. Tidsskrift for psykologi, 61, 4-18. 
Stolorow, R.D. (2007). Trauma and human existence: Autobiographical, psychoanalytic, and philosophical reflections. New York, NY: The Analytic Press.

Stolorow, R.D. \& Atwood, G.E. (1992). Context of being. The intersubjective foundations of psychological life. Hillsdale NJ: Analytic Press. 